профилактические мероприятия. На всех детей ЭГ подготовлены «Адаптационные листы», «Личная карта ребенка», для родителей «Дневник здоровья: Я и наш малыш!». На наш взгляд, такая форма обследования позволит наблюдать динамику психофизического состояния ребенка до поступления в школу.

Так, степень адаптации детей в ЭГ показала: легкая $80 \%$ детей и $20 \%$ средняя. Следовательно, дети ЭГ привыкли к детскому саду безболезненно. Эти данные позволяют судить о правильно построенной работе педагогического коллектива по проблеме адаптационного периода детей раннего возраста к условиям детского сада.

Таким образом, обобщая перспективы внедрения проекта «Вместе будем мы шагать в наш любимый детский сад!» в педагогический процесс экспериментальной группы МАДОУ ДС №3 нацеливает на гарантию успешной адаптации детей раннего дошкольного возраста к условиям детского сада; установлению доверительного общения между родителями ребенка, проходившим адаптацию и педагогами; преобразованию развивающей здоровьеформирующей среды групповой комнаты; повышению компетентности педагогов и родителей по проблеме психолого-педагогической адаптации детей раннего дошкольного возраста; повышению качества дошкольного образования в целом.

$$
* * *
$$

1. Дзидзоева С.М. Волонтерская деятельность как составляющая профессиональной компетенции студентов педвуза// Современные технологии в образовании / Сборник научных статей. Вып. XII. В 2-х частях. Часть 1. - Сев.-Осет. гос. пед. ин-т. - Владикавказ: Издательство СОГПИ. 2012. - 214 с. - С 100107.

2. Дзидзоева С.М. Психоэмоциональное здоровье дошкольника в условиях полилингвальной модели поликультурного образования как психолого-педагогическая проблема// Полилингвальное образование как основа сохранения языкового наследия и культурного разнообразия человечества: Материалы IV международной научной конференции. 12 ноября 2012 года (проводилась под эгидой ЮНЕСКО). Сев.Осет. гос. пед. ин-т: Владикавказ: Издательство СОГПИ, 2012. - 336 с.- С.92-95.

3. Ильина И.Ю. Аффективное поведение и его коррекция в младшем дошкольном возрасте. - М., 1996 //Электронный ресурс: dissercat.com>detei-mladshegovozrasta... iskusstva...

4. Макоева А.Г. Организация здоровьесберегающей и безопасной образовательной среды.// Образование, охрана труда и здоровье: материалы IV международной заочной научно-практической конференции 25 апреля 2014.- 414c. -С.173-185

5. Федеральный государственный образовательный стандарт дошкольного образования // Приказ Министерства образования и науки Российской Федерации (Минобрнауки России) от 17 октября 2013 г. N 1155 г. Москва.

6. Федеральный закон от 29.12.2012 N 273-Ф3 «Об образовании в Российской Федерации». - М., 2013.

\title{
Ким Т.C. \\ Интерактивные методы обучения иностранному языку (на примере корейского языка)
}

Университет мировой экономики и дипломатии (Узбекистан, Ташкент)

doi: 10.18411/lj-31-01-2018-10

idsp: 000001:lj-31-01-2018-10

\section{Аннотация}

Данная статья посвящена исследованию методики обучения студентов грамматической категории «Прошедшее время» с применением интерактивных методов. В исследовании предложен коммуникативно-творческий подход и синтез двух методов «Кейс-метода» и «Метода критического мышления». 
Ключевые слова: Актуальность статьи определила все возрастающая тенденция необходимости использования интерактивных методов в обучении корейскому языку.

Как известно, проблема повышения мотивации обучения иностранному языку требует от преподавателя коммуникативно-творческого подхода к eе решению, в частности, разработки более актуальных коммуникативных форм и методических приемов обучения.

В ходе подготовки занятия на основе интерактивных форм обучения перед преподавателем стоит задача выбора наиболее эффективной формы обучения для изучения конкретной темы, открывается возможность сочетать несколько методов обучения для решения проблемы, что способствует лучшему осмыслению студентов.

\section{1. Мозговой штурм}

Как известно, «Мозговой штурм» (англ. Brainstorming) - один из наиболее эффективных методов стимулирования творческой активности. Данный метод помогает найти оптимальное решение различных проблем путем правил обсуждения.

Метод «Мозговой штурма» позволил заинтересовать студентов на этапе введения определении темы для повторения изученного материала.

\section{2. Кластер}

Как известно, метод «Кластер» - поиск связанных с основным понятием лексических единиц и их графическое оформление в виде солнечной системы. Внутри, как солнце, ключевое слово, а далее планеты.

Метод кластера позволил эффективно объяснить основную лексику, связанную с понятием «Прошедшее время».

\section{3. Метод Кейс-стади - Case-stady - анализ ситуаций.}

Как известно, под ситуацией (кейсом) понимается письменное описание какой-то конкретной реальной ситуации. Особенности метода КС предполагают исследование реальной проблемы, на основе представленной количественной и качественной информации, поиск, выбор и обоснование пути решения проблемы, который, по мнению слушателя, является оптимальным в сложившейся обстановке. КС ставит обучающегося и преподавателя в позицию участника ситуации, который действует в реальных условиях и сталкивается с необходимость принимать решения и разрабатывать на их основе план действий.

Корейские исследователи эффективных методов обучения корейскому языку также особое внимание уделяют «Кейс-методу»

\section{4. Технология развития критического мышления}

Как известно данная технология способствует формированию разносторонней личности, способной критически относиться к информации, умению отбирать информацию для решения поставленной задачи.

Важно заметить, что при использовании технологии развития критического мышления овладение новыми знаниями начинается не со знакомства с известными способами решения определенной задачи или проблемы, а с создания условий, которые формируют потребность получить решение именно этой задачи.

\section{Мотивация:}

Преподавателям важно помнить, что в процессе обучения иностранному языку на практике важно не столько владение грамматическими знаниями, но прежде всего исчезновение языкового барьера, умение налаживать коммуникацию в команде, а также крайне важны эмоциональные впечатления от практического занятия. 
Комплексное решение практических, образовательных и развивающих задач обучения возможно лишь при условии воздействия не только на сознание учащихся, но и проникновения в эмоциональную сферу.

При работе с лингвострановедческим материалом создается хорошая предпосылка для всестороннего развития личности учащегося, так как специально отобранные песни стимулируют образное мышление и формируют хороший вкус.

На сегодняшний день метод изучения иностранного языка через песни и игры активно исследуется и используется преподавателями корейского языка непосредственно в Республике Корея.

Во время урока была использована презентация, включающая в себя грамматический комментарий, аудио и видеоматериал.

В целом были достигнуты все ожидаемые результаты, заключавшиеся в обучении студентов:

- правильно применять грамматические знания по теме;

- развить коммуникативную культуру и уметь работать в команде;

- уметь аналитически и критически мыслить на корейском языке;

- - -применять навык самостоятельной работы по заданной теме;

\section{Заключение}

Студенты проявили высокий интерес к интерактивным методам при обучении корейскому языку на практике. Применение «Кейс-метода» и метода «ТРКМ» для закрепления знаний по теме: «Прошедшее время» на материале песни «Миллион алых» в силу абсолютной новизны вызвало удивление положительную реакцию со стороны студентов.

Неудовлетворительный момент ожидаемых результатов состоял в том, что в силу новизны синтеза двух методов у студентов не хватает достаточного навыка критического суждения на корейском языке.

Преподавателям при построении занятия важно уделять внимание не только использованию различных новых педагогических технологий, но и разработке коммуникативного-творческого подхода к аудитории.

$$
* * *
$$

1. 최기영. 광운대학교. 외국어로서의 한국어 교육을 위한 학제 간 연계교과목의 개발 및 정보화에 관한 연구 결과보고서. 서울, 2007.

2. И.Б. Государев К вопросу о терминологии электронного обучения

3. ЧЕЛОВЕК И ОБРАЗОВАНИЕ № 1 (42) 2015, стр.180-183.

4. Власова Н.В. Современные образовательные технологии в контексте новых федеральных государственных образовательных стандартов [Текст] Н.В.Власова // Теория и практика образования в современном мире: материалы междунар. заоч. науч. конф. (г. Санкт-Петербург, февраль 2012 г.).

5. Гончарова М.В. Кейс-метод в обучении иноязычному общению менеджеров // Студент и учебный процесс: иностранные языки в высшей школе. Сборник научных статей / Под ред. Ю.Б. Кузьменковой. - М.: Центр по изучению взаимодействия 6 культур ФИЯ МГУ им. М.В.Ломоносова, 2004. (Дискуссионный клуб FLT: современные тенденции и опыт профессионалов. Вып. 5). С. 95-100.

6. Янг Юн Хи. Методы эффективного преподавания корейского языка, основанные на играх и изучении песнях. Университет Сонмун. - Сеул, 2005.

7. Практическая грамматика корейского языка. Цой С., Ким Хи И, Бэ Янг Сон. КОІСА. -Т., 2000. С. 198.

8. Чой Янг Сун. Корейский язык. Изд-во «Каро». - Санкт-Петербуг, 2007. С. 90

9. https://4brain.ru/blog/

10. http://tip.daum.net/question/

11. (http://festival.1september.ru/articles/512028/

12. http:/nsportal.ru/sites/default/files/2012/12 